\title{
Pengaruh Kemampuan Bernalar dan Penguasaan Kosakata terhadap Kemampuan Menulis Karangan Argumentasi
}

\author{
Sri Mulyati \\ Fakultas Pascasarjana, Universitas Indraprasta PGRI \\ Jalan Nangka No. 58 C/TB. Simatupang, Tanjung Barat, \\ Jakarta Selatan 12530 \\ sriarif70@gmail.com
}

\begin{abstract}
The aims of this research are to analyze and to test the truth of the hypothesis concerning the influence of reasoning ability and vocabulary mastery towards students' writing skill argumentative essay. Research hypotheses are tested include: 1) The influence of reasoning ability and vocabulary mastery at the same time towards students' writing skill argumentative essay, 2) The influence of reasoning ability towards students' writing skill argumentative essay, 3) The influence of vocabulary mastery towards students' writing skill argumentative essay. This research was conducted by survey method. The population was students at eighth grades of Mts Assubkiyah and Mts Nurul Ikhlas in Rawalumbu district of Bekasi. Amount of 80 students which taken in random proportional. Research instrument that had been used were reasoning test, vocabulary mastery test and writing skill argumentative essay test. Data analysis used was an analysis of variants (ANOVA) with two lines or way. The result of hypothesis test can be concluded were: 1) There was a significant influence of reasoning ability and vocabulary mastery at the same time towards students' writing skill argumentative essay, it has been proved with score test $\operatorname{sig}=0,000<0,05$ and $\mathrm{Fh}=69,186.2$ ) There was a significant influence of reasoning ability towards students' writing skill argumentative essay, it has been proved with score test sig $=0,000<0,05$ and Fh 8,128. 3) There was significant influence of vocabulary mastery towards students' writing skill argumentative essay, it has been proved with score test sig $=0,002>0,05$ and $\mathrm{Fh}=3,180$.
\end{abstract}

Keywords: Reasoning ability, vocabulary mastery, students' writing skill essay

\begin{abstract}
Abstrak
Penelitian bertujuan untuk menganalisis dan menguji kebenaran hipotesis mengenai pengaruh Kemampuan Bernalar dan Penguasaan Kosakata terhadap Kemampuan Menulis Karangan Argumentasi Siswa. Hipotesis penelitian yang diuji meliputi: 1) Pengaruh Kemampuan Bernalar dan Penguasaan Kosakata secara bersama-sama terhadap Kemampuan Menulis Karangan Argumentasi Siswa. 2) Pengaruh Kemampuan Bernalar terhadap Kemampuan Menulis Karangan Argumentasi Siswa. 3) Pengaruh Kemampuan Kosakata terhadap Kemampuan Menulis Karangan Argumentasi Siswa. Penelitian ini menggunakan metode survei. Populasi adalah siswa kelas VIII MTs Assubkiyah dan MTs Nurul Ikhlas di Kecamatan Rawalumbu Kota Bekasi dengan besar sampel sebanyak 80 siswa, dengan teknik random proporsioanal. Instrumen penelitian yang digunakan yaitu disajikan dalam bentuk tes kepada subjek penelitian, meliputi tes kemampuan bernalar, tes penguasaan kosakata, dan tes kemampuan menulis karangan Argumentasi. Analisis data menggunakan analysis of varians (ANOVA) dua jalur/arah.

Hasil pengujian hipotesis diperoleh simpulan sebagai berikut: 1) Terdapat pengaruh yang signifikan kemampuan dan penguasaan kosakata secara bersama-sama terhadap kemampuan menulis karangan argumentasi. Hal ini dibuktikan dengan perolehan nilai Sig $0,000<0,05$ dan $\mathrm{Fh}=69,186.2$ ). Terdapat pengaruh yang signifikan kemampuan bernalar terhadap kemampuan menulis karangan argumentasi. Hal ini dibuktikan dengan perolehan nilai Sig $0,000<0,05$ dan th $=8,128$. 3). Terdapat pengaruh yang signifikan penguasaan kosakata terhadap kemampuan menulis karangan argumentasi. Hal ini dibuktikan dengan perolehan nilai Sig 0,002 <0,05 dan th $=3,180$.
\end{abstract}


Kata Kunci: Kemampuan Bernalar, Penguasaan Kosakata, Kemampuan Menulis Karangan

\section{PENDAHULUAN}

Bahasa mempunyai fungsi utamanya yaitu sebagai alat komunikasi oleh setiap anggota masyarakat untuk saling mempengaruhi, bertukar pikiran, dan menyampaikan pesan. Di samping itu, bahasa juga mempunyai fungsi sebagai kebudayaan, fungsi pendidikan dan fungsi penalaran. Fungsi penalaran berhubungan dengan penggunaan bahasa yang jelas terarah yang merupakan perwujudan berfikir logis. Fungsi penalaran memberikan tekanan pada penggunaan bahasa sebagai alat berfikir. Fungsi kemasyarakatan berkaitan dengan fungsi-fungsi bahasa dalam kehidupan masyarakat. Siswa sebagai salah satu kelompok masyarakat intelektual diharapkan memiliki kemampuan bernalar, yang dalam tulisan ini disebut kemampuan gagasan penalaran. Dengan kemampuan gagasan penalaran, mereka dapat mengungkapkan pikiran gagasan dengan logis dan sistematis. Selain itu diperlukan penguasaan tata bahasa dan kemampuan memiliki kata yang baik, namun demikian kenyataan menunjukkan bahwa sebagian besar siswa, mengalami kesulitan mengungkapkan ide, gagasan dan pendapat serta merangkai kalimat dengan bahasa tulis. Kelemahan itu dapat dilihat dari sistematika organisasi dan melihat kata-kata yang digunakan dalam tulisan-tulisan, karangan dan karya ilmiah siswa.

Siswa dikatakan terampil berbahasa Indonesia apabila siswa tersebut telah menguasai sistem bahasa Indonesia secara keseluruhan. Keterampilan berbahasa yang lengkap mencakup empat keterampilan, yaitu mendengarkan atau memahami bahasa lisan atau sering juga disebut menyimak, berbicara, membaca atau memahami bahasa tulis, dan menulis. Keterampilan bahasa tersebut berbeda pada setiap orang. Kemungkinan seorang siswa menguasai semua keterampilan berbahasa sama baiknya. Siswa tertentu hanya menguasai keterampilan tertentu saja, misalnya terampil berbicara tetapi tidak terampil dalam menggunakan bahasa secara tertulis. Dari keempat aspek keterampilan berbahasa tersebut tampaknya pencapaian keterampilan menulislah yang paling memprihatinkan dari siswa. Berbagai hasil penelitian menunjukkan bahwa kemampuan siswa dalam menuangkan perasaan, gagasan atau pikiran secara logis dan sistematis dalam bahasa Indonesia pada umumnya masih sangat memprihatinkan.

Rendahnya kemampuan menulis siswa, salah satunya terlihat dari rendahnya partisipasi mereka dalam mengikuti berbagai kegiatan perlombaan menulis karya ilmiah. Sejauh hasil pengamatan penulis, setiap kali diselenggarakan lomba karya tulis ilmiah antar siswa dapat dipastikan pesertanya sedikit sekali. Hal ini disebabkan karena kurangnya pemahaman siswa dari hakikat, konsep, maupun teknik menulis. Dalam karya tulis, mereka banyak ditemukan penggunaan kata yang tidak tepat, penggunaan ejaan yang tidak cermat, pengorganisasian gagasan yang tidak logis dan tidak sistematis. Menulis merupakan suatu aktivitas yang kompleksitas, terletak pada tuntutan kemampuan mengharmonikan berbagai aspek. Seorang penulis perlu memiliki kekayaan dan keluwesan dalam mengungkapkan kemampuan mengendalikan emosi, serta menata dan mengembangkan daya nalarnya dalam berbagai level berpikir dan tingkat mengingat sampai ke evaluasi. Alex dan Achmad H.P (2010:6), mengemukakan bahwa "menulis merupakan suatu kegiatan unuk menciptakan suatu catatan pada suatu media dengan menggunakan aksara". Seorang penulis harus berani menampilkan kediriannya, termasuk pemikiran, perasaan dan gayanya serta menawarkannya kepada pembaca. Ia mungkin akan membaca, menyimak, mengamati, berdiskusi, berwawancara. Ia juga akan dapat memanfaatkan informasi itu. Cara mengumpulkan dan menyerap informasi bagi orang 
yang sekedar tahu untuk dirinya sendiri dan untuk disampaikan kembali kepada orang lain cenderung berbeda.

Khususnya menulis, latihan merupakan kunci yang paling utama demi mencapai kesuksesan untuk mencapai prediksi mampu menulis baik dan benar. Seperti yang dikemukakan oleh Tarigan (2008:104), "setiap manusia dapat memperoleh dan mengembangkan keterampilan menulis dengan menguasai konsep teoritis tertentu, disertai dengan latihan-latihan yang sudah pasti jatuh bangun dalam mencapai penguasaan keterampilan menulis. Berdasarkan beberapa pendapat di atas, dapat disimpulkan bahwa menulis adalah suatu kegiatan dalam menuangkan ide dengan menggunakan bahasa tulis sebagai media penyampaiannya.

Tujuan menulis yang paling utama adalah menginformasikan sesuatu kepada pembaca. Wirawan (2008:3-6), menyatakan bahwa "sebuah hobi yang bergairah tiada bandingnya adalah menulis". Banyak jenis tulisan yang memberikan inspirasi kepada dunia. Semuanya memiliki dasar tujuan untuk menyampaikan gagasan dan satu pemikiran ke pemikiran yang lain. Berbagai macam tulisan memiliki tujuan seperti: 1) Menghibur, dengan tulisan yang bertujuan untuk menghibur ini dapat menyentuh perasaan pembaca minimal dalam beberapa aspek tulisan anda. 2) Tulisan untuk menyampaikan informasi tulisan yang bertujuan untuk menyampaikan informasi. Untuk antisipasi ini akan lebih baik jika tulisan diselingi dengan sesuatu yang menghibur sehingga pembaca tidak cepat bosan, sedangkan informasi yang disampaikan dapat diterima pembaca dengan baik.

Semi (2007 :14-21), menyatakan "tujuan menulis adalah untuk menjelaskan sesuatu, meyakinkan dan untuk merangkum”. 1) Untuk menceritakan sesuatu. Menulis merupakan kegiatan untuk menceritakan sesuatu dari seorang penulis kepada pembacanya. Berdasarkan pengalaman dan imajinasinya. Penulis menceritakan semua pengalamannya ke dalam sebuah tulisan. 2) Untuk memberikan petunjuk dan pengarahan. Menulis merupakan menuangkan ide dan gagasan dalam sebuah tulisan. Penulis memberikan petunjuk atau pengarahan kepada pembaca. Dapat memberikan pengetahuan pada pembaca supaya tidak tersesat. 3) Untuk menjelaskan sesuatu. Menulis adalah menjelaskan sesuatu, melalui sebuah tulisan, pembaca akan mengerti bacaan tersebut karena pembaca sehingga setelah membaca seseorang akan meyakini apa yang dibacanya. 4) Untuk merangkum. Menulis merupakan rangkuman yang kemudian dijadikan menjadi satu.

Istilah argumentasi berasal dari kata argum yang berarti alasan dan bantahan. Kata argumentasi memiliki pengertian pemberian alasan untuk memperkuat atau menolak suatu pendapat atau gagasan. Keraf (2007:3) mengungkapkan bahwa "argumentasi berusaha mengajukan bukti-bukti untuk menyatakan sikap mengenai suatu hal". Dalam argumentasi, perlakuan terhadap suatu masalah dilakukan secara cermat dan teliti, bernada faktual, pokok permasalahan memang penting, dan maksud dan tujuannya adalah memperjuangkan keadilan, kebenaran dan kejujuran. "Argumentasi menuntut orangorang yang bertanggung jawab untuk menerima apa yang layak dan didasarkan pada fakta yang masuk akal". (Tarigan $2008:$ 116).

Istilah kemampuan argumentasi mencakup tiga konsep, yakni konsep kemampuan, menulis dan argumentasi. Konsep kemampuan (competence) dalam bahasa ini, mendasarkan pada konsep "kemampuan". Dalam linguistik competence dipandang sebagai " pengetahuan penutur pendengar tentang bahasanya", sedangkan performence dipandang sebagai " penggunaan bahasa secara aktual dalam situasi yang konkret". Dengan mengutip konsep kemampuan yang dikemukakan oleh Chomsky tersebut, 
kemampuan menulis argumentasi dapat diartikan sebagai penggunaan bahasa secara aktual dalam menulis argumentasi.

"Karangan merupakan hasil akhir dari percakapan merangkai kata dan alinea untuk menyatakan atau mengulas topik dan tema tertentu". (Finoza 2004: 192). Untuk menghasilkan tulisan yang baik, setiap penulis hendaknya memiliki tiga keterampilan dasar dalam menulis, yaitu keterampilan berbahasa, keterampilan penyajian, dan keterampilan pewajahan.. Semi (2007:4), menjelaskan bahwa "sekurang-kurangnya, ada tiga komponen yang tergabung dalam kegiatan menulis, yaitu: (1) penguasaan kosakata, diksi, struktur kalimat, paragraf, ejaan, dan sebagainya; (2) penguasaan isi karangan, dan (3) penguasaan tentang jenis-jenis tulisan.

Kemampuan menulis merupakan salah satu aspek keterampilan berbahasa dalam urutan kemampuan menyimak, berbicara, membaca dan menulis. Keraf (2007:3), mengungkapkan bahwa "argumentasi berusaha mengajukan bukti-bukri untuk menyatukan sikap mengenal suatu hal". Oleh karena itu, menulis pada hakekatnya bukan sekedar menuliskan simbol-simbol grafis sehingga membentuk kata, dan kata-kata itu disusun kembali menjadi kalimat. Akan tetapi menulis adalah menuangkan buah pikiran ke dalam tulisan melaluhi kalimat-kalimat yang dirangkai secara utuh, lengkap dan jelas sehingga dapat dikomunikasikan kepada pembaca dengan berhasil. Dalam proses menulis terdapat alur yang seharusnya diikuti oleh penulis. Penulis argumentasi menyampaikan ide-ide, fakta atau apapun yang dimilikinya dengan bebas. Adapun teknik argumentasi yang digunakan dalam tulisan argumentasi diantaranya: penggunaan pengalaman pribadi, penggunaan kenyataan, penggunaan analogi, pernyataan wewenang, dan antisipasi oposisi.

Apabila dikaji secara mendalam dari pendapat-pendapat di atas, tampak bahwa pada mulanya seorang penulis argumentasi hanya mengemukakan suatu penelitian terhadap suatu masalah, kemudian penulis argumentasi mengemukakan suatu pendirian terhadap suatu masalah, kemudian penulis argumentasi mempersoalkan sedemikian rupa sehingga pembaca menyetujui pendapatnya. Dengan demikian, dapatlah disimpulkan bahwa menulis argumentasi adalah suatu kegiatan mengemukakan secara tetulis ide-ide, gagasan, atau informasi yang bertujuan mempengaruhi orang lain dengan memaparkan bukti-bukti atau alasan-alasan yang kuat dan rasional. Berdasarkan beberapa pendapat di atas dapat disimpulkan bahwa pada hakekatnya tulisan argumentasi adalah sebuah tulisan yang bertujuan meyakinkan dengan cara mengemukakan alasan dan bukti-bukti yang kuat tentang sesuatu kebenaran.

Choesin (2004:49), menyatakan 'argumentasi merupakan inti dari bagian terbanyak penelitian ilmiah yang telah ada”. Dalam sebuah tulisan ilmiah penulis berusaha menyampaikan pendapatnya tentang suatu gejala konsep atau teori tentunya dengan tujuan bahwa ia dapat meyakinkan pembacanya akan kebenaran pendapatnya, oleh karena itu seorang penulis harus benar-benar memahami apa yang dimaksud dengan sebuah argumen. Akhadiah mengemukakan bahwa "tiga tahap yang harus dialami dalam proses penulisan, yaitu : (1) Pra penulisan, (2) Penulisan dan, (3) Revisi”. (Akhadiah, 1998:2).

Pada tahap pra penulisan kadang diperlukan stimulus untuk merangsang munculnya respon berupa ide atau gagasan. Cara biasa dilakukan antara lain membaca berbagai media cetak, menyimak warta berita, diskusi, pidato, seminar, dan lain-lain. Pada tahap penulisan diperlukan penguasaan kosakata untuk menyusun alenia sampai pada penyusunan karangan secara utuh. Sementara itu pada tahap revisi dilakukan koreksi terhadap keseluruhan karangan, penilaian kembali apa yang sudah ditulis, memperbaiki, mengubah, bahkan jika perlu memperluas tulisan. Pada tahap ini penulis meneliti secara 
menyeluruh mengenai logika, sistematika, ejaan, tanda baca, pilihan kata, kalimat, paragraf, pengetikan catatan kaki, dan sebagainya. Dalam pelaksanaannya ketiga tahap penulisan tersebut jelas tidak dapat dipisahkan

Menurut Lakhsmi (2008:1), bahwa "tulisan argumentasi adalah tulisan yang ditulis bertujuan meyakinkan pembaca untuk menyetujui fakta, norma, alasan, dalih, dan kesimpulan dari sautu pandangan". Tujuan argumentasi yang bagus akan menyatakan posisinya dengan jelas, diikuti dengan argumen-argumennya yang jernih dan runtut, serta ditutup dengan deduksi yang tidak melenceng dari topik debat". Untuk menulis argumentasi harus diperhatikan beberapa hal yang menjadi landasannya, yaitu: masalah penalaran, yakni merumuskan pendapat yang benar sebagai proses berpikir untuk mengaitkan fakta-fakta menuju suatu kesimpulan yang dapat diterima oleh akal sehat, corak penalaran, mengadakan penilaian atau penolakan (kalau perlu) atas pendapat orang lain yang pernah dicetuskan, terakhir menyusun tulisan argumentasi. Dengan dapat disimpulkan bahwa hakekat tulisan argumentasi adalah tulisan yang bertujuan meyakinkan dengan cara mengemukakan alasan dan bukti-bukti yang kuat tentang suatu kebenaran.

Secara konseptual kemampuan menulis argumentasi adalah kemampuan yang dimiliki dalam menuangkan ide/ gagasan dan mengorganisasikan ide tersebut secara runtut dan sistematis ke dalam bentuk argumentasi dengan kaidah yang ditetapkan. Berpikir dan bernalar merupakan dua istilah yang saling berkaitan. Kedua kata tersebut memiliki hubungan pengertian, yaitu akal budi. Apabila dikaji secara mendalam, kedua istilah tersebut memiliki makna yang berbeda. "Dalam proses bernalar (penalaran) selalu terkandung kegiatan berpikir, sedangkan dalam proses berpikir tidak terkandung kegiatan bernalar". (Suriasumantri,1993:42).

Berpikir tidak dapat dipisahkan dari kehidupan manusia. Berpikir dapat dilakukan oleh setiap orang. "Kegiatan berpikir yang dilakukan secara sadar, tersusun dalam urutan saling berhubungan dan bertujuan untuk mendapatkan kesimpulan, kegiatan tersebut adalah bernalar". (Akhadiah,1998:41). Dengan demikian dapat dinyatakan bahwa bernalar adalah suatu kegiatan berpikir lebih tinggi daripada berpikir biasa. Bernalar dilakukan melalui proses tertentu untuk mencapai kesimpulan."Proses pemikiran berhubungan erat dengan seluruh tingkah laku individu. Sebagai proses kognitif, proses itu tidak dapat disusun secara langsung, sehingga tidak dapat dipahami melalui tingkah laku yang nyata. Lagi pula proses itu dipengaruhi secara terus menerus oleh bermacammacam faktor diantaranya emosi dan motivasi”. (Vinacke, 1974:72-74).

Selanjutnya Vinacke, membedakan dua jenis pemikiran, yakni pemikiran imajinasi dan pemikiran yang bersifat ekspresif dan relatif bebas dari pengaruh luar. Penalaran mencakup pemikiran logis, pembentukan konsep, transfer dan pemecahan masalah. Jenis pemikiran ini lebih dipengaruhi oleh faktor luar sehingga lebih realistis. Dewey (1964:1-7), mengemukakan bahwa "pemikiran adalah proses yang terdiri dari rangkaian gambaran mental tentang sesuatu yang tak hadir secara nyata". Poespoprodjo (1985:174), menyatakan bahwa "proses pemikiran adalah suatu pergerakan mental dari suatu hal ke hal lain, dari proposal lainnya, dan dari apa yang sudah diketahui ke hal yang belum diketahui". Melalui bernalar, maka dapat diperoleh pengetahuan. Pencapaian pengetahuan melaluhi penalaran itu terjadi secara tidak langsung, yaitu melaluhi mediasi. Selain pencapaian pengetahuan penalaran dengan mediasi, harus dilakukan secara sadar dan dilandasi dengan suatu tujuan tertentu.

Pengetahuan yang dihasilkan dari proses kegiatan penalaran biasa bersifat ilmiah dan bukan ilmiah. Penalaran ilmiah memliki ciri tertentu, tidak sama dengan penalaran 
non ilmiah. Tentunya penalaran ilmiah memiliki ciri-ciri ilmiah, yaitu sesuai dengan metode ilmiah. Suriasumantri (1993:42), mengemukakan bahwa "sebagai suatu kegiatan berpikir penalaran mempunyai ciri tertentu, yaitu logis dan analitik". Penalaran ilmiah merupakan suatu kegiatan analitik yang mempergunakan logika ilmiah. Sifat logis menunjukkan penalaran yang dilakukan dengan mematuhi pola pemikiran (logika) tertentu, sedangkan sifat analitis menunjukkan bahwa penalaran dilakukan langkahlangkah sebagai konsekuensi digunakan pola-pola pikiran itu. Sejalan dengan pendapat itu, Arifin dan Tasai (1997:17), mengatakan bahwa "generalisasi adalah proses penalaran yang mengandalkan beberapa pertanyaan yang mempunyai sifat tertentu untuk mendapatkan kesimpulan yang bersifat umum".

"Logika induktif dapat berupa generalisasi, analogi dan hubungan kausal". (Akhadiah, 1998:91). Bentuk yang pertama, yaitu generalisasi adalah proses penalaran berdasarkan pengamatan dan sejumlah gejala dengan sifat-sifat tertentu untuk menarik kesimpulan mengenai semua atau sebagian dari gejala yang serupa. Bentuk logika yang kedua adalah analogi. Dalam analogi, inferensi tentang kebenaran gejala khusus ditarik berdasarkan gejala khusus yang bersamaan. Analogi yang dimaksud adalah analogi induktif. Analogi induktif adalah suatu proses penalaran untuk menarik kesimpulan/inferensi tentang kebenaran suatu gejala khusus lain yang memiliki sifat-sifat esensial penting yang bersamaan.

Keraf (1980:90) "membedakan antara perbandingan dengan analogi, perbandingan menunjukan kesamaan antara barang-barang dalam kelas yang sama, sebaliknya analogi menunjukkan kesamaan antara dua barang atau hal yang berlainan”. Selanjutnya, bentuk ketiga logika induktif adalah hubungan kausal. Maksudnya, hubungan ketergantungan antara gejala-gejala yang mengikuti pola-pola sebab akibat, akibat sebab, atau akibat. Bentuk kausal tersebut apat dijumpai dalam kehidupan sehari-hari, karena apabila diperhatikan pada setiap peristiwa mempunyai sebab, dan sebab tersebut mungkin dapat diketahui apabila seseorang berusaha untuk menyelidiki. Penyelidikan tersebut akan terlaksana apabila seorang mempunyai pengetahuan yang memadai. Suriasumantri (1979:195) mengemukakan bahwa "penalaran ilmiah adalah sintesis antara penalaran induktif dan deduktif untuk memperolah pengetahuan. Lebih lanjut dikemukakan bahwa cara induktif menyangkut cara berpikir empiris dan deduktif menyangkut cara berpikir rasional".

Dewey (1964:95), mengemukakan bahwa "ada lima langkah penting dalam pemikiran reflektif yang pada dasarnya dapat dikatakan sebagai penerapan gabungan proses induktif dan deduktif. Langkah-langkah itu mencakup pengenalan masalah, perumusan masalah, perumusan hipotesis, pengumulan dan analisis fakta serta verifikasi". Untuk melakukan kegiatan berpikir dengan baik maka digunakan bermacammacam sarana, yaitu berupa bahasa, logika, matemaika, dan statistika. Dalam kaitannya dengan tulisan ini dibahas sarana pertama, yaitu bahasa. Bahasa merupakan sarana komunikasi verbal yang digunakan dalam seluruh proses bernalar. Dengan demikian, dapat disimpulkan bahwa penalaran ilmiah memiliki ciri-ciri sebagai berikut: ada tujuan, memiliki premis berupa pengalaman atau pengetahuan bahkan teori yang telah diketahui, memiliki pola pemikiran tertentu, memiliki sifat empiris rasional.

Penguasaan pada hakikatnya adalah bagian dan ranah kognitif. Bloom (1977:718), mengemukakan bahwa "hasil belajar dibedakan ke dalam katagori atau ranah (domain), yaitu ranah kognitif, efektif, dan psikomotor". Ranah kognitif bertalian dengan aspek pengetahuan dan kemampuan intelektual sesorang. Ranah ini terdiri dari enam tingkatan, yaitu ingatan, pemahaman penerapan, analistis, sintetis, dan evaluasi. Ranah afektif meliputi perasaan (feeling), nada, emosi, dan variasi tingkatan penerimaan dan 
penolakan terhadap sesuatu, sedangkan ranah psikomotorik berkaitan dengan hasil belajar yang menyangkut gerakan-gerakan otot. Penguasaan merupakan suatu hasil belajar.

Gagne dan Briggs (1979:45-50), menegaskan bahwa "terdapat lima katagori hasil belajar, yakni; (1) keterampilan intelektual yaitu kecakapan yang membuat orang berkompeten, yaitu memungkinkan untuk menanggapi konseptualisasi lingkungannya atau sering disebut pengetahuan prosedural, (2) strategi kognitif yaitu kemampuan yang mengatur sesorang untuk memilih cara, (3) informasi verbal yaitu kemampuan menyatakan suatu gagasan atau informasi atau sering disebut pengetahuan deklaratif, (4) kemampuan motorik yaitu kemampuan melakukan gerakan dalam sejumlah tindakan motorik yang terorganisir, dan (5) sikap". Pendapat tersebut sama-sama melihat pengetahuan dan penguasaan sebagai suatu hasil belajar. Hasil belajar yang diperoleh seesorang itu dapat berupa penguasaan. Bloom menempatkan penguasaan ke dalam aspek kemampuan kognitif. Dengan demikian, maka dapat disimpulkan bahwa penguasaan adalah kemampuan terhadap sesuatu yang telah dipelajari.

Sebagai salah satu komponen kebahasaan, kosakata memiliki arti yang beragam . Menurut Dale (yang dikutip Tarigan), bahwa "Kosakata merupakan bagian dan sistem bahasa yang berinteraksi dalam pola-pola sintaksis" (Tarigan, 1984:21). Kosakata merupakan suatu unsur bahasa yang sangat penting. Semua bahasa mempunyai kosakata yang antara satu bahasa dengan yang lain tidak sama jumahnya, sedangkan menurut Vallete, "Kosakata adalah kata atau kelompok kata yang memiliki makna tertentu". Valette, (1977:73). Soedjito (2009:1), "mengartikan kosakata sebagai berikut: 1) Semua kata yang terdapat dalam suatu bahasa, 2). Kekayaan kata yang dimiliki oleh sesorang pembicara atau penulis, 3) Kata yang dipahami dalam suatu bidang ilmu pengetahuan, 4). Daftar kata yang disusun seperti kamus disertai penjelasan secara singkat dan praktis".

Keraf menambahkan bahwa "kekayaan kosakata seseorang memungkinkan kecermatan berbahasanya" (Gorys Keraf, 1988:22). Keraf mengatakan bahwa untuk memperkaya kata-kata itu dan mempergunakanya kosakata bukan sekedar memiliki katakata itu dan mempergunakan sesuka hati, tetapi menguasai kata-kata itu dan mempergunakannya secara tepat untuk mewakili gagasan-gsgasan dalam kesepakatan dan konteks yang cocok. "Pemilihan kata adalah proses atau tindakan memilih kata yang dapat mengungkapkan gagasan secara tepat" (Mustakim, 1994:41).

Dalam kegiatan berbahasa, pilihan kata merupakan aspek yang sangat penting karena pilihan kata yang tidak tepat selain dapat menyebabkan ketidakefektifan bahasa yang digunakan, juga dapat mengganggu kejelasan informasi dan rusaknya situasi komunikasi tidak jarang disebabkan oleh pemilihan kata yang tidak tepat", (Mustakim, 1994:14). Ini berarti setiap kata memiliki makna tertentu yang berbeda dengan kata yang lain. Walaupun ada beberapa kata yang secara sekilas tampaknya memiliki makna yang hampir sama, tetapi jika diteliti lebih seksama lagi, akan tampaklah masing-masing kata itu memiliki perbedaan. Karena itu, dalam menguasai kosakata tidak hanya melalui terjemahan kata demi kata, tetapi juga harus dikaitkan dengan kalimat atau konteknya. Oleh karena itu, perlu diketahui juga apakah kata tersebut digunakan dalam ungkapan yang berbentuk majas atau bukan, sebab kata yang digunakan dalam ungkapan yang memiliki makna konotatif harus ditafsirkan tidak secara leksikal.

Nababan (1993:118) menjelaskan bahwa "sinonim adalah kata yang sama atau hampir sama artinya, sedangkan antonim adalah kata yang berlawanan artinya". Septriyanti, (2012:339-425), menegaskan bahwa kegiatan menulis ialah menyusun katakata dalam kalimat yang memenuhi kaidah tata bahasa. Tanpa penguasaan kosakata yang cukup maka terjadi hambatan dalam menulis. Dengan demikian, dapat dikatakan bahwa 
kualitas penguasaan kosakata penting bagi seorang dalam menuangkan ide dan pikirannya terutama dalam bentuk tulisan. Kosakata memegang peranan penting dalam kegiatan menulis .

Dalam menulis dimulai dengan penguasaan sejumlah kosakata. Sejumlah kosakata tersebut selanjutnya digunakan secara tepat. Setelah itu kosakata disusun menjadi kalimat atau akhirnya membentuk wacana. Agar kegiatan menulis berjalan lebih baik, diperlukan penguasaan kosakata secara baik dan mendalam dan cermat dalam penggunaannya. Untuk menuangkan ide, gagasan, dan pikiran, seorang penulis dituntut menguasai makna kata itu dengan baik. Menguasai makna kata dengan baik dapat diperoleh dengan menguasai sinonim, antonim, homonim kata tersebut. Sinonim adalah kata-kata yang mengandung arti yang sama tetapi berbeda dalam nilai kata. Antonim adalah kata yang mengandung makna yang berbalikan atau berlawanan dengan kata yang lain, sedangkan homonim adalah kata-kata yang bunyinya sama tetapi maknanya berlainan.

Hubungan makna antara dua buah kata yang sinonim bersifat dua arah. Jadi, kata bunga bersinonim dengan kata kembang, maka kata kembang bersinonim dengan kata bunga. Meskipun demikian, dua buah kata yang bersinonim itu, kesamaannya tidak seratus persen. Kesamaannya tidak bersifat mutlak, sebab prinsip umum semantik mengatakan apabila bentuk berbeda maka maknapun akan berbeda. Jadi, makna kata mati dan meninggal, misalnya tidak persis sama. Ketidakmungkinan menukarkan sebuah kata dengan kata lain yang bersinonim banyak sebabnya, antara lain karena : (1) faktor waktu, misalnya kata hulubalang dengan kata komandan; keduanya tidak mudah dipertukarkan karena kata hulubalang hanya cocok untuk situasi kuno, klasik, sedangkan komandan hanya cocok untuk situasi kini; (2) faktor tempat atau daerah, misalnya kata saya dan beta. Kata beta hanya cocok untuk digunakan dalam konteks emakaian bahasa di Maluku, sedangkan kata saya dapat digunakan secara umum; (3) faktor sosial, misalnya kata aku dan saya, dua buah kata yang bersinonim, tetapi kata aku hanya dapat dipergunakan untuk teman sebaya dan tidak dapat digunakan kepada orang yang lebih tua atau status sosialnya lebih tinggi, dan (4) faktor nuansa makna, misalnya kata melihat dan melirik merupakan kata yang bersinonim. Kata melihat dapat digunakan secara umum, tetapi kata melirik hanya digunakan untuk melihat dengan sudut mata.

Tarigan (1984:83), mengungkapkan bahwa "antonim (yang terdiri dari anti atau ant yang berarti lawan ditambah akar kata onim atau onuma yang berarti nama), yaitu kata yang mengandung makna berbalikan atau berlawanan dengan kata lain".Hubungan makna antara dua buah kata yang berantonim bersifat dua arah, namun demikian tidak bersifat mutlak. Istilah lain ialah oposisi makna. Berdasarkan sifatnya, oposisi ini dapat dibedakan menjadi (1) oposisi mutlak, pertentangan makna secara mutlak, contoh kata gerak atau diam. Sesuatu yang (ber)gerak tentu tidak dalam keadaan diam; dan sesuatu yang diam tentu tidak dalam keadaan (ber)gerak. Kedua proses ini tidak berlangsung secara bersamaan, melainkan secara bergantian , (2) oposisi kutub, yakni makna kata bergradasi. Artinya terdapat tingkat-tingkat makna kata, misalnya kaya dan miskin, (3) oposisi hierakial, yakni makna kata yang menyatakan suatu deret jenjang atau tingkatan. Berupa satuan ukuran yang menyatakan berat. Mustakim menambahkan bahwa seseorang dalam mengungkapkan gagasan, perasaan, dan pikirannya hendaknya dapat memenuhi kriteria dalam pemilihan kata meliputi ketepatan, kecermatan dan keserasian. Sesuai dengan pendapat di atas dapat disimpulkan bahwa "Penguasaan kosakata adalah kemampuan memilih kata yang tepat, kata sinonim dan kata antonim dalam mengungkapkan gagasan pada kesempatan dan konteks yang cocok". (Mustakim, 1994:12). 


\section{METODE}

Metode yang digunakan dalam penelitian ini adalah survei dengan pendekatan korelasional untuk memperoleh data mengenai variabel kemampuan bernalar $\left(X_{1}\right)$, penguasaan kosakata $\left(\mathrm{X}_{2}\right)$, dan kemampuan menulis argumentasi $(\mathrm{Y})$.

Sampel adalah sebagian atau wakil populasi yang diteliti (Arikunto, 1996: 104). Setelah diketahui hasil randomisasi, jika kelas-kelas yang menjadi populasi tersebut memiliki peluang atau kesempatan yang sama untuk dijadikan sebagai sampel penelitian, maka akan ditetapkan secara random. Adapun sampel dalam penelitian ini adalah $15 \%$ dari 536 siswa yaitu 80 siswa. Sampel dari masing-masing sekolah yang tergabung di dalam kelas VIII MTs Nurul Ikhlas dan MTs As Subkiyah diambil secara random proporsional.

Instrumen yang dipergunakan dalam penelitian ini disajikan dalam bentuk tes kepada subjek penelitian, meliputi tes kemampuan penalaran, tes penguasaan kosakata, dan tes kemampuan menulis argumentasi.

Variabel kemampuan menulis argumentasi terlihat dari skor yang diperoleh responden dengan menggunakan instrumen kemampuan menulis argumentasi dengan tes esai. Aspek yang diukur dalam kemampuan menulis argumentasi meliputi (1) pembuatan gagasan, (2) pengorganisasian gagasan mencakup kesatuan dan kepaduan, (3) keefektifan kalimat, penggunaan pungtuasi, (4) pemakaian ejaan yang benar, dan (5) pemakaian evidensi. Responden diminta membuat sebuah tulisan argumentasi dengan ketentuan sebagai berikut (1) memilih salah satu topik yang telah disediakan, kemudian menentukan judul tulisan, (2) mempergunakan bahasa yang baik dan benar, (3) di dalam tulisan tersebut tercermin problematika, argumentasi, dan kesimpulan, (4) panjang tulisan 1-2 halaman atau kurang lebih 200-300 kata, dan (5) Waktu yang disediakan bagi responden adalah 90 menit. Instrumen yang mengukur 5 aspek kemampuan menulis argumentasi inilah yang disebut instrumen final untuk mengukur kemampuan menulis argumentasi.

Variabel kemampuan bernalar tercermin dari skor yang diperoleh responden dengan menggunakan instrumen kemampuan bernalar berbentuk tes dengan empat pilihan jawaban yang terdiri dari 30 butir soal. Skor kemampuan bernalar dari seluruh butir soal memiliki rentangan skor teoretik antara 1 sampai 30. Skor yang didapat responden sesuai dengan jawaban yang diperoleh mengerjakan tes obyektif melalui pilihan ganda dengan lima pilihan jawaban. Empat pilihan jawaban yang lain merupakan pengecoh (distraktor). Jawaban yang benar diberi bobot nilai 1 yang salah diberi bobot nilao 0. Kisi-kisi instrumen untuk mengukur kemampuan bernalar yang akan disajikan pada bagian ini menggambarkan keseluruhan instrumen yang diujicobakan. Dengan menyisihkan butir yang gugur dari yang dipergunakan maka diperoleh instrumen final. Penyajian dilakukan dengan memberikan informasi mengenai butir-butir yang didrop setelah dilakukan uji validasi dan uji reabilitas butir. Dengan demikian berarti instrumen final telah mencerminkan indikator dari variabel kemampuan bernalar siswa.

Variabel penguasaan kosakata terlihat dari skor yang diperoleh responden dengan menggunakan instrumen penguasaan kosakata berbentuk tes dengan lima pilihan jawaban yang terdiri dari 29 butir soal. Skor penguasaan kosakata dari seluruh butir soal memiliki rentangan skor teoritik 1 sampai dengan 29. Skor yang didapat responden sesuai dengan jawaban yang diperoleh mengerjakan tes obyektif melaluhi pilihan ganda dengan lima pilihan jawaban. Empat pilihan jawaban yang lain merupakan pengecoh (distraktor). Jawaban yang benar diberi bobot nilai 1 yang salah diberi bobot nilai 0. Skor yang didapat responden sesuai dengan jawaban yang diperoleh mengerjakan tes penguasaam 
kosakata. Aspek penguasaan kosakata yang diukur mencakup; (a) pemilihan kosakata, (b) pemakaian kosa kata, (c) pemakaian kata antonim. Sedangkan aspek kognitif yang diukur adalah (a) ingatan, (b) pemahaman, (c) penerapan, (d) analisis, (e) sintesis, (f) evaluasi.

Analisis deskriptif dilakukan teknik penyajian data dalam bentuk tabel distribusi frekuensi, grafik poligon, dan histogram untuk masing-masing variabel penelitian. Selain itu juga masing-masing kelompok data akan diolah dan dianalisis ukuran pemusatan dan letak mean, median, dan modus, serta ukuran simpangan seperti jangkauan, variansi, simpangan baku, kemencengan, dan kurtosis. Untuk perhitungan analisis deskriptif digunakan program SPSS version 22.0 for Windows.

Setelah keseluruhan uji persyaratan analisis data dipenuhi dan diketahui data layak untuk diolah lebih lanjut. Langkah berikutnya adalah menguji masing-masing hipotesis yang telah diajukan. Pengujian hipotesis yang dilakukan adalah dengan menggunakan teknik korelasi regresi linier berganda. Hal ini digunakan untuk mencari pengaruh antarvariabel, yaitu pengaruh kemampuan bernalar terhadap kemampuan menulis karangan argumentasi, pengaruh penguasaan kosakata terhadap kemampuan menulis karangan argumentasi, dan pengaruh kemampuan bernalar dan penguasaan kosakata secara bersama-sama terhadap kemampuan menulis karangan argumentasi. Pengujian dalam perhitungan uji hipotesis juga digunakan bantuan program SPSS.

\section{HASIL DAN PEMBAHASAN}

Deskripsi data statistik dari hasil perhitungan dan pengujian yang dilakukan dengan bantuan komputer melalui program aplikasi SPSS 24.0, serta analisis dan intepretasinya.

Tabel 1. Deskripsi Data Penelitian

\begin{tabular}{|c|c|c|c|c|}
\hline \multicolumn{5}{|c|}{ Statistics } \\
\hline & & $\begin{array}{l}\text { Kemampuan } \\
\text { Bernalar }\end{array}$ & $\begin{array}{l}\text { Penguasaan } \\
\text { Kosakata }\end{array}$ & $\begin{array}{l}\text { Kemampuan Menulis } \\
\text { Karangan Argumentasi }\end{array}$ \\
\hline \multirow{2}{*}{$\mathrm{N}$} & Valid & 80 & 80 & 80 \\
\hline & Missing & 0 & 0 & 0 \\
\hline \multicolumn{2}{|c|}{ Mean } & 68,99 & 74,53 & 76,05 \\
\hline \multicolumn{2}{|c|}{ Median } & 67,00 & 76,00 & 76,00 \\
\hline \multicolumn{2}{|c|}{ Std. Deviation } & 9,558 & 8,460 & 11,359 \\
\hline \multicolumn{2}{|c|}{ Skewness } & ,408 &,- 078 &,- 147 \\
\hline \multicolumn{2}{|c|}{$\begin{array}{l}\text { Std. Error of } \\
\text { Skewness }\end{array}$} & ,269 & ,269 & ,269 \\
\hline \multicolumn{2}{|c|}{ Kurtosis } &,- 547 &,- 661 &,- 600 \\
\hline \multicolumn{2}{|c|}{ Std. Error of Kurtosis } &, 532 &, 532 &, 532 \\
\hline \multicolumn{2}{|c|}{ Range } & 40 & 37 & 47 \\
\hline \multicolumn{2}{|c|}{ Minimum } & 50 & 55 & 51 \\
\hline \multicolumn{2}{|c|}{ Maximum } & 90 & 92 & 98 \\
\hline \multicolumn{2}{|c|}{ Sum } & 5519 & 5962 & 6084 \\
\hline
\end{tabular}


Vol. 1, No. 1, April 2018, pp. 67-81

p-ISSN: 2615-4935

e-ISSN: 2615-4943

Multiple modes exist. The smallest value is shown

\section{Analisis Data Kemampuan Menulis Karangan Argumentasi (Y)}

Data kemampuan menulis karangan argumentasi yang diperoleh dari para responden mempunyai rata-rata 76.050 dengan simpangan baku 11.3594, median sebesar 76.000, skor minimum 51 dan skor maksimum 98. Hal ini menunjukkan bahwa rata-rata kemampuan menulis karangan argumentasi dari responden termasuk tinggi. Skor simpangan baku 11.359, menunjukkan perbedaan jawaban antar responden termasuk tinggi. Hal ini menunjukkan bahwa kemampuan menulis karangan argumentasi dari responden cukup beragam.

Dari deskriptif data tersebut juga dapat dilihat bahwa antara nilai rata-rata dan dan nilai tengah (median) hampir sama, yaitu 76.05 dan 76.00. Hal ini menunjukkan bahwa data skor kemampuan menulis karangan argumentasi pada penelitian ini cukup representatif. Sedangkan skor yang berada di atas rata-rata lebih banyak dibanding yang berada di bawah rata-rata, menunjukkan bahwa kemampuan menulis karangan argumentasi yang berada diatas rata-rata lebih banyak dibanding yang dibawah rata-rata.

\section{Analisis Data Variabel Pengaruh Kemampuan Bernalar $\left(\mathbf{X}_{1}\right)$}

Pengaruh kemampuan bernalar yang diperoleh dari para responden mempunyai ratarata 68.99. dengan simpangan baku 9.558, median sebesar 67.00. Pengaruh kemampuan bernalar minimum 50 dan pengaruh kemampuan bernalar maksimum 90. Angka simpangan baku sebesar 9.558, menunjukkan perbedaan pengaruh kemampuan bernalar antar responden termasuk rendah. Hal ini menunjukkan bahwa pengaruh kemampuan bernalar dari responden tidak banyak beragam.

\section{Analisis Data Penguasaan Kosakata $\left(\mathbf{X}_{2}\right)$}

Skor penguasaan kosakata yang diperoleh dari para responden mempunyai ratarata 74,53dengan simpangan baku 8,460, median 67,00 skor minimum 37 dan skor maksimum 92. Dari deskripsi tersebut juga dapat dilihat bahwa antara nilai rata-rata dan dan nilai tengah (median) hampir sama, yaitu 74.53 dan 76,00 Hal ini menunjukkan bahwa data penguasaan kosakata yang diperoleh pada penelitian ini cukup representatif. Sedangkan skor yang berada di atas rata-rata lebih banyak dibanding yang berada di bawah rata-rata menunjukkan bahwa responden yang mempunyai penguasaan kosakata yang baik lebih banyak dibanding yang tidak.

Tabel 2. Rekapitulasi Hasil Pengujian Normalitas One-Sample Kolmogorov-Smirnov Test

$\begin{array}{lll}\text { Pengaruh } & & \text { Kemampuan } \\ \text { Kemampuan } & \text { Penguasaan } & \text { menulis } \\ \text { Bernalar } & \text { Kosakata } & \text { karangan } \\ \text { argumentasi }\end{array}$

$\mathrm{N}$

\begin{tabular}{|c|}
\hline $\begin{array}{l}\text { Normal } \\
\text { Parameters }{ }^{\mathrm{a}, \mathrm{b}}\end{array}$ \\
\hline $\begin{array}{l}\text { Most } \\
\text { Extreme }\end{array}$ \\
\hline
\end{tabular}

\section{0}

63.18

7.151

.106

.056
80

61.20

7.086

.076

.064 
Diskursus: Jurnal Pendidikan Bahasa Indonesia

Vol. 1, No. 1, April 2018, pp. 67-81

p-ISSN: 2615-4935

e-ISSN: $2615-4943$

\begin{tabular}{lrrr}
\hline Differences Negative & $\mathbf{- . 1 0 6}$ & $\mathbf{- . 0 7 6}$ & $\mathbf{- . 0 6 0}$ \\
Kolmogorov-Smirnov Z & $\mathbf{. 9 4 4}$ & $\mathbf{. 6 7 9}$ & $\mathbf{. 6 9 6}$ \\
Asymp. Sig. (2-tailed) & $\mathbf{. 3 3 5}$ & $\mathbf{. 7 4 6}$ & $\mathbf{. 7 1 7}$
\end{tabular}

a. Test distribution is Normal.

b. Calculated from data.

Pada tabel di atas terlihat bahwa nilai pada kolom Sig pada metode KolmogorovSmirnov untuk semua sampel lebih besar dari 0,05 , sehingga $\mathrm{H}_{0}$ diterima, dengan kata lain bahwa data dari semua sampel pada penelitian ini berdistribusi normal.

Hasil perhitungan pengujian linieritas garis regresi hubungan antara variabel bebas kemampuan bernalar terhadap variabel terikat kemampuan menulis karangan argumentasi dapat dilihat pada tabel di bawah ini.

Tabel 3. Rekapitulasi Hasil Pengujian Linieritas Garis Regresi Hubungan Antara Variabel $\mathbf{X}_{1}$ dengan Variabel $Y$

\begin{tabular}{|c|c|c|c|c|c|c|c|}
\hline \multicolumn{8}{|c|}{ ANOVA Table } \\
\hline & & & $\begin{array}{c}\text { Sum of } \\
\text { Squares }\end{array}$ & $d f$ & $\begin{array}{c}\text { Mean } \\
\text { Square }\end{array}$ & $\mathrm{F}$ & Sig. \\
\hline \multirow{5}{*}{$\begin{array}{l}\text { Kemampuan } \\
\text { Menulis } \\
\text { Karangan } \\
\text { Argumentasi * } \\
\text { Kemampuan } \\
\text { Bernalar }\end{array}$} & \multirow{3}{*}{$\begin{array}{l}\text { Between } \\
\text { Groups }\end{array}$} & (Combined) & $6,938,508$ & 24 & 289,104 & 4,885 & 000 \\
\hline & & Linearity & $6,070,652$ & 1 & $6,070,652$ & 102,567 &, 000 \\
\hline & & Deviation from Linearity & 867,855 & 23 & 37,733 & 638 & 882 \\
\hline & \multicolumn{2}{|c|}{ Within Groups } & $3,255,292$ & 55 & 59,187 & & \\
\hline & \multicolumn{2}{|l|}{ Total } & $10,193,800$ & 79 & & & \\
\hline
\end{tabular}

Pada tabel di atas terlihat bahwa nilai pada kolom Sig baris deviation fromLinierity $=0,882$ untuk semua sampel lebih dari 0,05 , sehingga $\mathrm{H}_{0}$ diterima, dengan kata lain bahwa garis regresi hubungan antara varibel $\mathrm{X}_{1}$ dan variabel $\mathrm{Y}$ linier.

\section{Tabel 4. Rekapitulasi Hasil Pengujian Linieritas Garis Regresi Hubungan Antara} Variabel $\mathbf{X}_{2}$ dengan Variabel $\mathbf{Y}$ 
Diskursus: Jurnal Pendidikan Bahasa Indonesia

Vol. 1, No. 1, April 2018, pp. 67-81

p-ISSN: 2615-4935

e-ISSN: $2615-4943$

\begin{tabular}{|c|c|c|c|c|c|c|c|}
\hline \multicolumn{8}{|c|}{ ANOVA Table } \\
\hline & & & $\begin{array}{l}\text { Sum of } \\
\text { Squares }\end{array}$ & df & $\begin{array}{l}\text { Mean } \\
\text { Square }\end{array}$ & $F$ & Sig. \\
\hline \multirow{5}{*}{$\begin{array}{l}\text { Kemampuan } \\
\text { Menulis } \\
\text { Karangan } \\
\text { Argumentasi }{ }^{*} \\
\text { Penguasaan } \\
\text { Kosakata }\end{array}$} & \multirow{3}{*}{$\begin{array}{l}\text { Between } \\
\text { Groups }\end{array}$} & (Combined) & $5,274,152$ & 25 & 210,966 & 2,316 & ,005 \\
\hline & & Linearity & $3,422,443$ & 1 & $3,422,443$ & 37,566 &, 000 \\
\hline & & Deviation from Linearity & $1,851,709$ & 24 & 77,155 &, 847 & 665 \\
\hline & \multicolumn{2}{|c|}{ Within Groups } & $4,919,648$ & 54 & 91,105 & & \\
\hline & \multicolumn{2}{|l|}{ Total } & 10193,80 & 79 & & & \\
\hline
\end{tabular}

Pada tabel di atas terlihat bahwa nilai pada kolom Sig baris deviation fromLinierity $=0,665$ untuk semua sampel lebih dari 0,05 , sehingga $\mathrm{H}_{0}$ diterima, dengan kata lain bahwa garis regresi hubungan antara varibel $\mathrm{X}_{2}$ dan variabel $\mathrm{Y}$ linier.

Tabel 5. Hasil Perhitungan Koefisien Korelasi Pengaruh Variabel $X_{1}$ dan $X_{2}$ terhadap Variabel Y

\begin{tabular}{llrrr}
\hline & \multicolumn{4}{c}{ Model Summary } \\
Model & $\mathrm{R}$ & $\mathrm{R}$ Square Adjusted R Square & Std. Error of the Estimate \\
1 &, $802^{\mathrm{a}}$ &, 642 &, 633 & 6,880
\end{tabular}

a. Predictors: (Constant), Penguasaan Kosakata, Kemampuan Bernalar.

Tabel 6 Rekapitulasi Hasil Perhitungan Persamaan Garis Regresi Pengaruh Variabel $X_{1}$ dan $X_{2}$ terhadap Variabel $Y$

\begin{tabular}{|c|c|c|c|c|c|}
\hline \multicolumn{6}{|c|}{ Coefficients $^{\mathrm{a}}$} \\
\hline \multirow[t]{2}{*}{ Model } & $\begin{array}{r}\text { Unstand } \\
\text { Coeffi }\end{array}$ & $\begin{array}{l}\text { rdized } \\
\text { lents }\end{array}$ & $\begin{array}{l}\text { Standardized } \\
\text { Coefficients }\end{array}$ & $\mathrm{T}$ & ig. \\
\hline & B & Std. Error & Beta & & \\
\hline (Constant) & $-1,905$ & 7,289 & &,- 261 & ,794 \\
\hline $\begin{array}{l}\text { Kemampuan } \\
\text { Bernalar }\end{array}$ & 765 & ,094 & 644 & 8,128 & ,000 \\
\hline $\begin{array}{l}\text { Penguasaan } \\
\text { Kosakata }\end{array}$ & ,338 & , 106 & ,252 & 3,180 & ,002 \\
\hline
\end{tabular}

a. Dependent Variable: Kemampuan Menulis Karangan Argumentasi

Tabel 7 Rekapitulasi Hasil Perhitungan Pengujian Signifikasi Koefisien Regresi Pengaruh Variabel $X_{1}$ dan $X_{2}$ dengan Variabel $Y$

\section{ANOVA $^{\text {a }}$}




\begin{tabular}{lrrrrr}
\hline Model & \multicolumn{1}{c}{ Sum of } & Df & Mean Square & F & \multicolumn{1}{l}{ Sig. } \\
& Squares & & & & \\
Regression & 6549,301 & 2 & 3274,650 & 69,186 &, $000^{\mathrm{b}}$ \\
Residual & 3644,499 & 77 & 47,331 & & \\
Total & 10193,800 & 79 & & &
\end{tabular}

a. Dependent Variable: Kemampuan Menulis Karangan Argumentasi

b. Predictors: (Constant), Penguasaan Kosakata, Kemampuan Bernalar

Berdasarkan tabel di atas, terlihat bahwa koefisien korelasi ganda pengaruh variabel bebas kemampuan bernalar $\left(\mathrm{X}_{1}\right)$ dan penguasaan kosakata $\left(\mathrm{X}_{2}\right)$ secara bersamasama terhadap kemampuan menulis karangan argumentasi siswa (Y) adalah sebesar 0,802 . Sedangkan koefisien determinasinya (R square) sebesar 0,642 menunjukan bahwa besarnya kontribusi kemampuan bernalar dan penguasaan kosakata secara bersama-sama terhadap kemampuan menulis karangan argumentasi adalah sebesar 64,2\%, sisanya (sebesar 35,8\%) disebabkan faktor lainnya.

Untuk pengujian hipotesis melalui analisis regresi diperoleh hasil perhitungan persamaan garis regresi yang merepresentasikan pengaruh variabel $X_{1}$ dan $X_{2}$ terdahap variabel $\mathrm{Y}$, yaitu $\widehat{\mathbf{Y}}=-1.905+0,765 \mathrm{X}_{1}+0,338 \mathrm{X}_{2}$. Pengujian signifikansi garis regresi tersebut adalah dengan memperhatikan hasil perhitungan yang ada pada Tabel 4.9. Menurut ketentuan yang ada, kriteria signifikansi regresi tersebut adalah "jika $\mathbf{S i g}<0.05$, maka $\mathrm{H}_{0}$ ditolak" atau "jika $\mathbf{F}_{\text {hitung }}>\mathbf{F}_{\text {tabel }}$, maka $\mathrm{H}_{0}$ ditolak", yang berarti bahwa koefisien regresi tersebut signifikan, dengan kata lain terdapat pengaruh yang signifikan variabel bebas $\mathrm{X}_{1}$ dan $\mathrm{X}_{2}$ terhadap variabel terikat $\mathrm{Y}$. Nilai Sig adalah bilangan yang tertera pada kolom Sig dalam Tabel 4.8. Nilai $\mathbf{F}_{\text {hitung }}$ adalah bilangan yang tertera pada kolom $\mathbf{F}$ dalam Tabel 4.9. Sedangkan nilai $\mathbf{F}_{\text {tabel }}$ adalah nilai tabel distribusi $\mathbf{F}$ untuk taraf nyata $5 \%$ dengan derajat pembilang $(\mathrm{k})=2$ dan derajat penyebut $(\mathrm{n}-\mathrm{k}-1)=77$ dimana $\mathrm{n}$ adalah banyaknya responden, dan $\mathrm{k}$ adalah banyaknya variabel bebas.

Dari tabel terlihat bahwa nilai Sig $=0.000$ dan $\mathbf{F}_{\text {hitung }}=69,186$, sedangkan $\mathbf{F}_{\text {tabel }}=$ 3,11. Karena nilai $\mathbf{S i g}<0,05$ dan $\mathbf{F}_{\text {hitung }}>\mathbf{F}_{\text {tabel }}$ maka $\mathrm{H}_{0}$ di tolak yang berarti bahwa koefisien regresi tersebut signifikan. Dengan kata lain bahwa terdapat pengaruh yang signifikan variabel bebas pengaruh kemampuan bernalar $\left(\mathrm{X}_{1}\right)$ dan penguasaan kosakata $\left(\mathrm{X}_{2}\right)$ secara bersama-sama terhadap Variabel terikat kemampuan menulis karangan argumentasi (Y). Dari hasil pengujian korelasi maupun regresi tersebut maka bisa disimpulkan bahwa terdapat pengaruh yang signifikan variabel bebas pengaruh kemampuan bernalar $\left(\mathrm{X}_{1}\right)$ dan penguasaan kosakata $\left(\mathrm{X}_{2}\right)$ secara bersama-sama terhadap kemampuan menulis karangan argumentasi $(\mathrm{Y})$.

Dari tabel terlihat bahwa nilai Sig $=0.000$ dan $\mathbf{t}_{\text {hitung }}=8,128$, sedangkan $\mathbf{t}_{\text {tabel }}=$ 1,99. Karena nilai Sig $<0,05$ dan $\mathbf{t}_{\text {hitung }}>\mathbf{t}_{\text {tabel, }}$, maka $\mathrm{H}_{0}$ di tolak yang berarti terdapat pengaruh yang signifikan variabel bebas $\mathrm{X}_{1}$ (pengaruh kemampuan bernalar) terhadap variabel terikat $\mathrm{Y}$ (kemampuan menulis karangan argumentasi). Dari hasil pengujian regresi tersebut maka bisa disimpulkan bahwa terdapat pengaruh yang signifikan variabel bebas $\mathrm{X}_{1}$ (pengaruh kemampuan bernalar) terhadap variabel terikat $\mathrm{Y}$ (kemampuan menulis karangan argumentasi). Dari tabel terlihat bahwa nilai Sig $=0.002$ dan $\mathbf{t}_{\text {hitung }}=$ 3.180, sedangkan $\mathbf{t}_{\text {tabel }}=1$,99. Karena nilai $\mathbf{S i g}<0,05$ dan $\mathbf{t}_{\text {hitung }}>\mathbf{t}_{\text {tabel }}$ maka $\mathrm{H}_{0}$ di tolak yang berarti terdapat pengaruh yang signifikan variabel bebas $\mathrm{X}_{2}$ (Penguasaan Kosakata) terhadap variabel terikat Y (Kemampuan Menulis Karangan Argumentasi). Dari hasil pengujian regresi tersebut, dapat disimpulkan bahwa terdapat pengaruh yang signifikan 
variabel bebas $\mathrm{X}_{2}$ (penguasaan kosakata) terhadap variabel terikat $\mathrm{Y}$ (kemampuan menulis karangan argumentasi).

\section{SIMPULAN}

1. Terdapat pengaruh yang signifikan kemampuan bernalar dan penguasaan kosakata secara bersama-sama terhadap kemampuan menulis agumentasi. Hal itu dibuktikan dengan perolehan nilai Sig 0,000 $<0,05$ dan $F_{h}=69,186$.

2. Terdapat pengaruh yang signifikan kemampuan bernalar terhadap kemampuan menulis argumentasi . Hal ini dibuktikan dengan perolehan nilai Sig. 0,000 $<0,05$ dan $t_{h}=8,128$.

3. Terdapat pengaruh yang signifikan penguasaan kosakata terhadap kemampuan menulis argumentasi. Hal ini dibuktikan dengan perolehan nilai Sig. 0,002 $<0,05<$ dan $t_{h}=3,180$.

\section{DAFTAR PUSTAKA}

Alex, \& Ahmad,H.P. (2010). Bahasa Indonesia untuk perguruan tinggi. Jakarta: Kencana.

Akhadiah,S. (1998). Pembinaan kemampuan menulis bahasa Indonesia. Jakarta: Erlangga.

Arifin,Z. \& Tasai,A. (1997). Cermat berbahasa Indonesia. Jakarta: Meditama Sarana Perkasa.

Bloom,B. (1977). Taxonomy of educational objectiva. New York : David.Mc, Kay Company.

Choesin,M.E. (2004). Karya tulis ilmiah sosial. Jakarta: Yayasan Obor Indonesia.

Dewey,J. (1964). How we think. Chicago: Hendry Regnery Company.

Finoza,L. (2004). Komposisi bahasa Indonesia. Jakarta: Insan Mulia.

Gagne,R. \& Briggs,L. (1979). Principles of intructional design. New York: Holt Rinerhart and Wiston.

Keraf,G. (2007). Argumentasi dan eksposisi. Jakarta: PT. Gramedia Pustaka.

Keraf,G. (1994). Komposisibahasa Indonesia. Jakarta: Penerbit: Nusa Indah.

Keraf,G. (2000). Diksi dan gaya bahasa. Jakarta: PT. Gramedia Pustaka

Lakhsmi. (2008). Bengkel menulis mengoposisi serangan argumentasi.http://sepocikopi.com/2008/10/24/bengkel

Mustakim. (1994). Membina kemampuan berbahasa. Jakarta: Gramedia Pustaka Utama.

Nababan,SUS. (1993). Pengajaran semantik. Bandung: Angkasa

Soedjito. (2009). Kosakata bahasa Indonesia. Jakarta: Gramedia PustakaUtama.

Tarigan,H.G. ( 2008). Menulis sebagai keterampilan berbahasa. Bandung: Angkasa.

Tarigan,H.G. (1984). Prinsip-prinsip dasar sintaksis. Bandung: Angkasa.

Tarigan,H.G. (1995). Pengajaran semantik. Bandung: Angkasa. 